\title{
Edukasi Literasi Digital Remaja dalam Memerangi Narkoba
}

\author{
Dedi Saputra*1, Eri Bayu Pratama $^{2}$, Muhamad Syarif ${ }^{3}$, Weishky Steven Dharmawan ${ }^{4}$ \\ Universitas Bina Sarana Informatika Kampus Pontianak \\ Jl. Abdurrahman Saleh No.18A Pontianak, (0561)583924 \\ e-mail: *1dedi.dst@bsi.ac.id
}

\begin{abstract}
Abstrak
Edukasi yang dilakukan Pemerintah dalam mencegah penyalahgunaan Narkoba di kalangan remaja tanpa henti. Pemerintah melalui kebijakan yang tertuang dalam Undang-undang Nomor 35 tahun 2009 tentang narkotika mengatur fungsi pencegahan di semua kalangan terutama pada kelompok muda yakni pelajar dan mahasiswa yang memiliki masa depan yang panjang dan merupakan generasi emas bangsa. Tujuan pelaksanaan kegiatan Pengabdian Kepada Masyarakat (PKM) ini menggunakan sosialisasi dan edukasi literasi digital tentang memerangi penyalahgunaan Narkoba. Kegiatan ini bekerjasama dengan BNN provinsi Kalimantan Barat dengan sasaran pelajar SMA yang ada di Kota Pontianak. Hasil kegiatan diharapkan berdampak pada pemahaman tentang bahaya Narkoba dan pencegahannya dikalangan pelajar dengan memanfaatkan teknolgi digital sebagai media literasi dalam memerangi Narkoba.
\end{abstract}

Kata Kunci: BNN; Edukasi; Literasi Digital; Narkoba; Teknologi Digital

\section{Pendahuluan}

Data World Drugs Reports 2021 dari kanto PBB untuk Narkoba dan Kejahatan-The United Nations Office on Drugs and Crime (UNODC) yang dirilis 24 Juni 2021 menyatakan bahwa sekitar 275 juta orang menggunakan narkoba di seluruh dunia pada tahun lalu, sementara lebih dari 36 juta orang menderita gangguan penggunaan narkoba (UNODC, 2021). Selain itu, sebagian besar negara telah melaporkan peningkatan penggunaan ganja selama pandemi. Dalam survei profesional kesehatan di 77 negara, 42 persen menyatakan bahwa penggunaan ganja telah meningkat. Peningkatan penggunaan obat-obatan farmasi non-medis juga telah diamati pada periode yang sama. antara 2010-2019 jumlah orang yang menggunakan narkoba meningkat sebesar 22 persen, sebagian karena pertumbuhan populasi global. Berdasarkan perubahan demografis saja, proyeksi saat ini menunjukkan peningkatan 11 persen dalam jumlah orang yang menggunakan narkoba secara global pada tahun 2030 dan peningkatan yang nyata sebesar 40 persen di Afrika, karena pertumbuhan pesat dan populasi mudanya. Menurut perkiraan global terbaru, sekitar 5,5 persen dari populasi berusia antara 15 dan 64 tahun telah menggunakan narkoba setidaknya sekali dalam satu tahun terakhir, sementara 36,3 juta orang, atau 13 persen dari total jumlah orang yang menggunakan narkoba, menderita gangguan penggunaan narkoba. Escarra global, lebih Dari 11 junta orang diperkirakan menggunakan 
narkoba suntik, setengahnya hidup dengan Hepatitis C. Opioid terus menjadi beban penyakit terbesar yang dikaitkan dengan penggunaan narkoba.

Berdasarkan data dari Badan Narkotika Nasional (BNN), penyalahgunaan narkoba di Indonesia mengalami peningkatan 0,03\% pada 2019 dibandingkan 2017. Dengan kata lain, pada 2019, tercatat ada 3,6 juta pengguna narkoba, 63\% di antaranya pengguna ganja. Dari angka 3,6 juta pengguna narkoba, mengungkapkan, 70\% di antaranya adalah masyarakat dalam usia produktif, yakni 16-65 tahun. Yang lebih menyedihkan lagi, dari angka tersebut, sebanyak $27 \%$ pengguna narkoba dari kalangan pelajar dan mahasiswa.(Lenny Tristia Tambun / BW, 2021). Kepala BNN RI Dr. Petrus Reinhard Golose mengatakan dalam sebuah kesempatan memberikan materi terkait Bagaimana Penanggulangan Narkoba di Era Pandemi Covid-19 untuk Menuju Indonesia Bersih Narkoba atau Bersinar. Kepala BNN RI Dr. Petrus Reinhard Golose menyampaikan paparan terkait Kondisi ancaman NPS atau Narkotika Jenis Baru di Indonesia. Dimana saat ini terdapat 83 NPS yang beredar di Indonesia dan 75 NPS sudah diatur dalam Permenkes RI Nomor 4 Tahun 2021 tentang perubahan Penggolongan Narkotika dan masih terdapat 8 NPS yang belum diatur dalam Permenkes (Akbar et al., 2020). Selain itu, Kepala BNN RI juga menyampaikan contoh New Psychoactive Substance (NPS) Di Indonesia yang paling banyak digunakan oleh kalangan pelajar dan mahasiswa di Indonesia adalah jenis tembakau gorila. Tembakau banyak digunakan karena cukup populer di Indonesia, mudah diperoleh, harga yang murah dan tidak memiliki aroma yang aneh. Kondisi Geografi, Demografi dan Kerawanan juga menjadi pengaruh besar dalam peredaran narkotika di Indonesia. Diperlukan Strategi dan Kebijakan BNN RI dalam menanggulanginya. Strategi yang digunakan oleh BNN RI adalah Hard Power Approach yaitu dengan pemberantasan dan penegakan hukum yang terukur, kemudian ada Soft Power Approach yaitu dengan pencegahan, pembedayaan masyarakat dan Rehabilitasi dan yang selanjutnya adalah Smart Power Approach yaitu dengan IT Development dan kerja sama Domestik, Regional dan Internasional. Kepala BNN RI juga, menyampaikan bagaimana peran pelajar dan mahasiswa dalam penganggulangan narkotika adalah dengan menunjukkan kepribadian yang baik dan akhlak yang terpuji serta tidak terpengaruh oleh peer group pressure untuk mencoba narkotika, Karena mahasiswa adalah agen perubahan dalam pencegahan narkotika dan menjadi relawan anti narkoba di sekolah maupun kampus (Humas BNN, 2021).

Sementara itu angka penyalahgunaan narkoba di kalangan pelajar pada 2018 di 13 provinsi termasuk Kalimantan Barat mencapai angka 2,29 juta orang. Salah satu kelompok masyarakat yang rawan terpapar penyalahgunaan narkoba adalah mereka yang berada pada rentang usia 15-35 tahun (Saufi \& Kismartini, 2019). Berdasarkan data dari Badan Narkotika Nasional 
Provinsi Kalimantan Barat, ternyata peredaran narkotika internasional masuk ke Indonesia khususnya wilayah Kalimantan Barat sekarang melalui jalur-jalur perbatasan (Saputra, 2021). Jaringan narkotika internasional ini terus mencari celah untuk masuk dengan tetap target Indonesia sebagai pangsa pasar potensial (Gafar, 2011). Pemerintah Indonesia bekerjasama dengan Malaysia untuk mampu mengurangi ataupun menghambat perdagangan narkoba yang terjadi di wilayah perbatasan Indonesia dan Malaysia (Gabriella, 2019). Dengan adanya Forum General Border Committee ( $G B C$ ) Indonesia-Malaysia (Malindo) yang merupakan forum kerjasama perbatasan bertujuan untuk dapat menjaga stabilitas keamanan kedua negara khususnya untuk perbatasan di kedua negara (Priangani et al., 2020). Pencegahan narkoba tidak sebanding lurus dengan tingkat peningkatan kasus penyalahgunaan dikalangan pelajar, lembaga Kepolisian dan BNN belum sepenuhnya mampu membuat pencegahan yang efektif baik pada pencegahan umum, didalam dan diluar rumah tangga hingga lingkungan masyarakat (Kareth \& Shintasari, 2020)(Azhar et al., 2021).

\section{Metode}

Kegiatan pencegahan narkoba mengenal tiga cara yakni promotif, preventif dan advokasi yang berbentuk komunikasi, informasi dan edukasi baik kepada pemuda yang tidak maupun yang sudah terjerumus dan peran organisasi masyarakat untuk melakukan penyuluhan, konsultasi, dan pengawasan perilaku dengan pendekatan keagamaan, hukum dan Kesehatan (Bakker et al., 2020). Kegiatan PKM ini menggunakan metode ceramah dalam mengedukasi peserta tentang pemahaman Narkoba dan bagaimana cara pencegahan penyalahgunaannya. Diakhir sesi dilakukan diskusi dan tanya jawab mengenai materi yang telah disampaikan oleh pemateri.

\section{Hasil dan Pembahasan}

\subsection{Waktu dan Tempat}

Pelaksanaan Pengabdian Kepada Masyarakat dengan tema "Edukasi Literasi Digital Remaja dalam Memerangi Narkoba" bekerjasama antara Tim PKM Universitas Bina Sarana Informatika Kampus Pontianak dengan BNN Provinsi Kalimantan Barat, yang dilaksanakan di 5 sekolah di wilayah Kota Pontianak yaitu: SMA Kapuas, SMAN 6, SMK Mandiri, SMKN 8 dan SMK Al-Madani dengan peserta merupakan pelajar/siswa disekolah tersebut. Dari tanggal 22 s.d 24 November 2021 dimulai pukul 09.00 sampai dengan 12.00 wib. Secara keseluruhan, kegiatan PKM ini berjalan suskes dan lancar. Peserta yang mengikuti kegiatan ini dan panitia (tim PKM) tetap memperhatikan protokol kesehatan yang diinstruksikan dari pemerintah dengan memakai masker, mencuci tangan dan tempat duduk diberi jarak satu sama lain. Lebih 
jelasnya, berikut ini diberikan foto dokumentasi suasana pada saat kegiatan edukasi berlangsung.

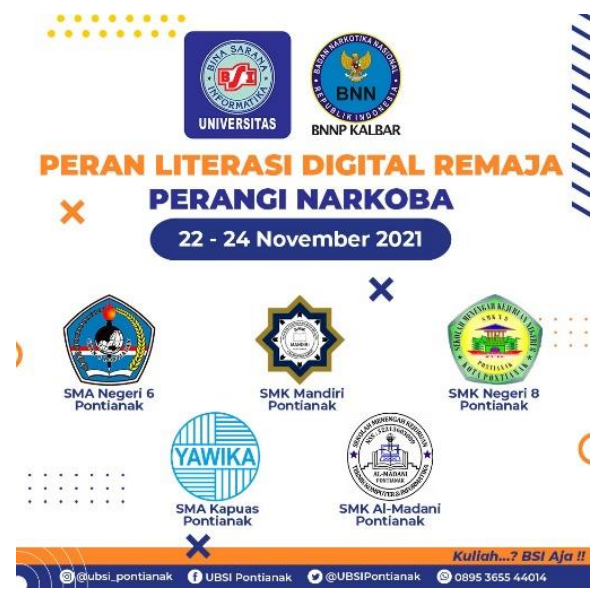

Gambar 1. Flyer Kegiatan yang dipublish di Media Sosial

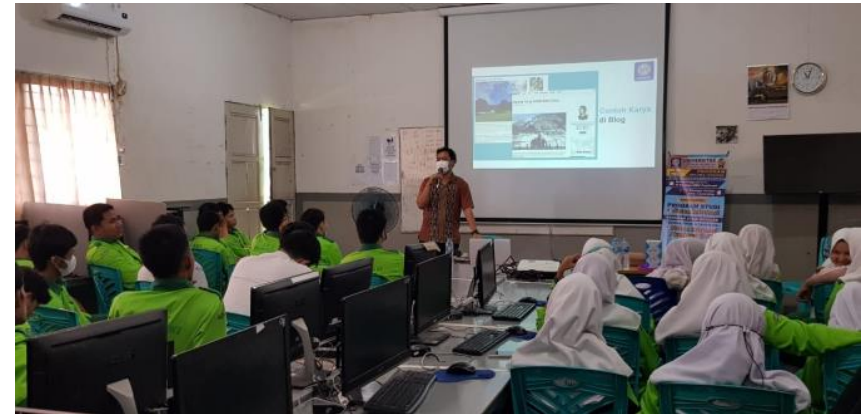

Gambar 2. Suasana Kegiatan di SMK Al-Madani

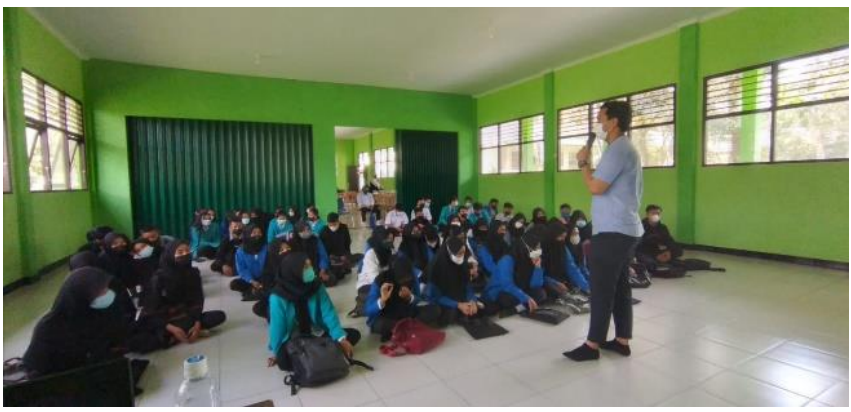

Gambar 3. Suasana Kegiatan di SMKN 8

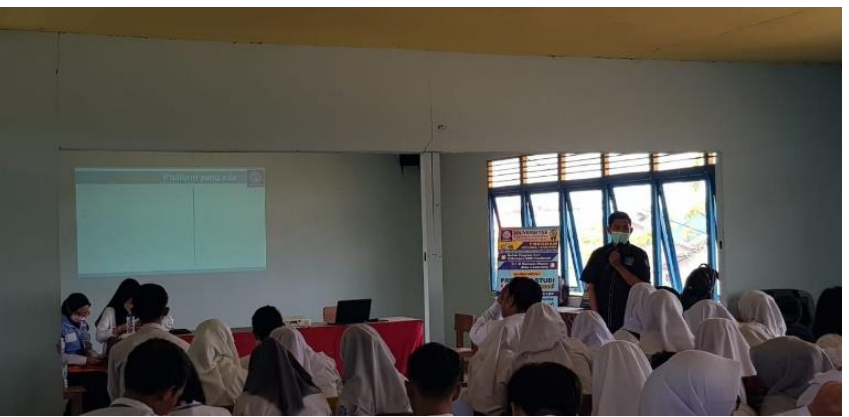

Gambar 4. Suasana Kegiatan di SMK Mandiri 


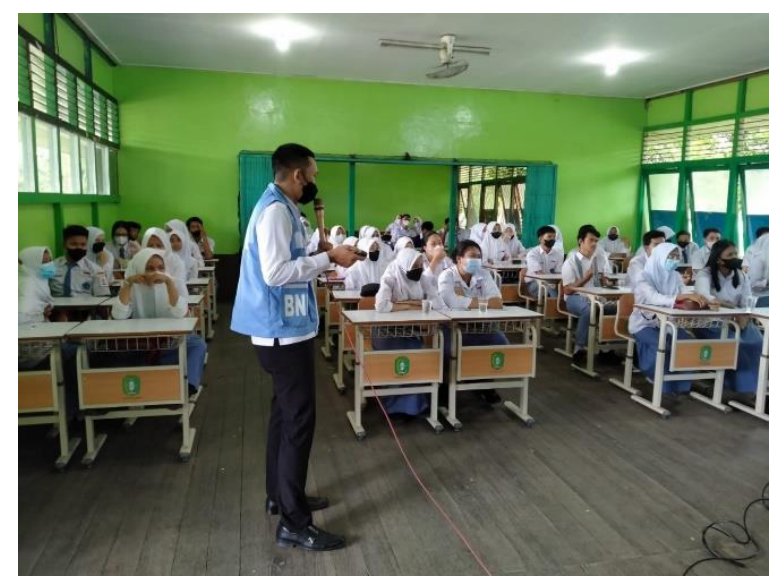

Gambar 5. Suasana Kegiatan di SMAN 6

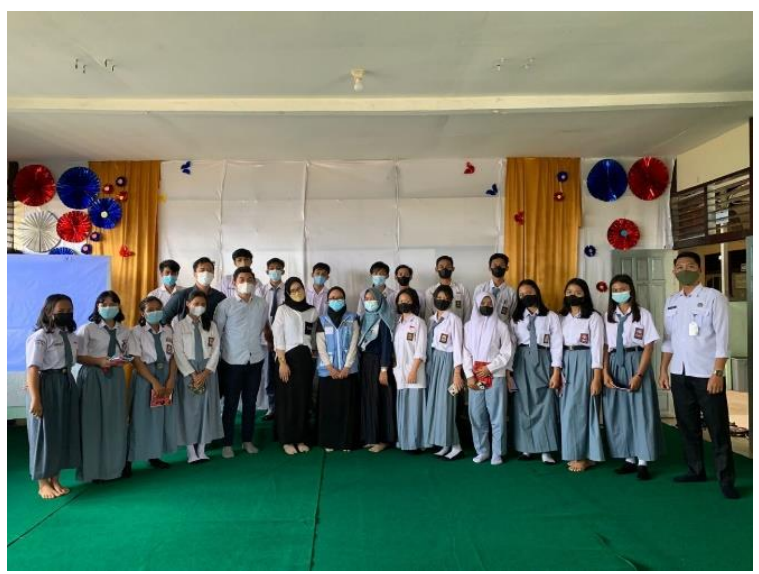

Gambar 6. Suasana Kegiatan di SMA Kapuas

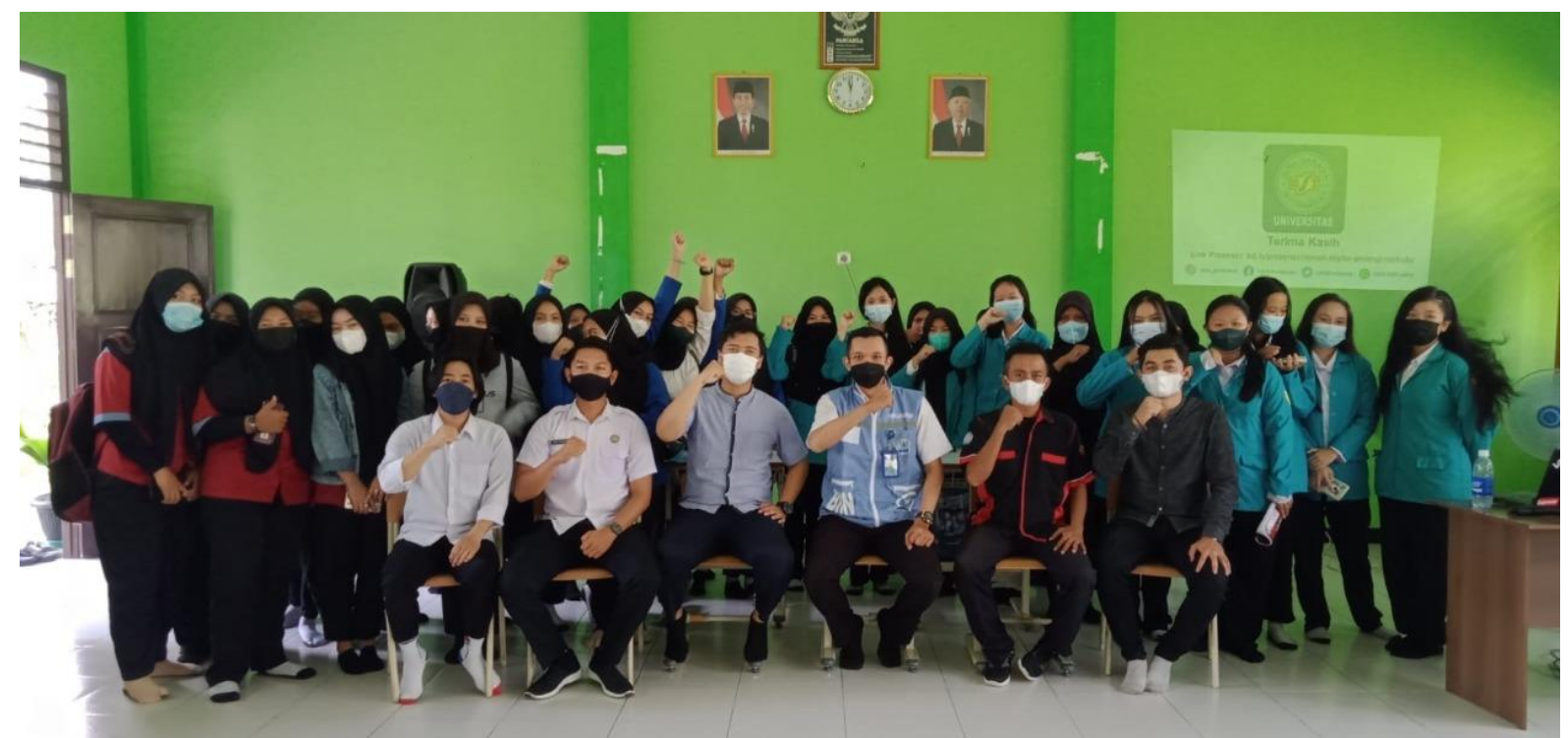

Gambar 7. Foto Bersama Tim PKM, BNN dan Peserta

\subsection{Penerapan Kegiatan}

Penerapan kegiatan dengan sasaran peserta adalah kalangan pelajar SMA di kota Pontianak. Kota Pontianak merupakan ibu kota Provinsi Kalimantan Barat dengan luas wilayah Kota 
Pontianak mencapai 107,82 km2 yang terdiri dari 6 kecamatan dan 29 kelurahan.(Saputra \& Rafiqin, 2017). Kecamatan di Kota Pontianak yang mempunyai wilayah terluas adalah Kecamatan Pontianak Utara 34,52\%, Kecamatan Pontianak Barat 15,71\%, Kecamatan Pontianak Kota 14,39\%, Kecamatan Pontianak Tenggara 13,75\%, Kecamatan Pontianak Selatan 13,49\% dan terakhir Kecamatan Pontianak Timur 8,14\%. Secara keselurahan Kota Pontianak berbatasan dengan wilayah Kabupaten Mempawah dan Kabupaten Kubu Raya. Wilayah Kota Pontianak banyak terdapat sungai dan parit yang keseluruhannya berjumlah 61 sungai/parit. Sebagian masyarakat masih memanfaatkan sungai/parit untuk kebutuhan seharihari dan sungai/parit tersebut juga sebagai penunjang sarana dan prasarana.

\subsection{Pelaksanaan Kegiatan}

Berdasarkan hasil diskusi sebelum penyampaian materi, masih banyak peserta yang belum mengenal dan memahami dengan baik tentang NARKOBA dan sejenisnya, dan bagaimana menyikapinya dan mencegahnya. Materi disampaikan oleh Nara sumber dari BNN Provinsi Kalbar dan Satu Orang Narasumber dari Tim PKM. Pelaksanaan dilakukan secara road show dari satu sekolah kemudian hari berikutnya sekolah yang lain.

\section{Kesimpulan}

Kegiatan pencegahan dan pemberdayaan organisasi masyarakat patut ditingkatkan oleh BNN sebagai pioner dalam gerakan penanggulangan bahaya narkoba. BNN belum maksimal melakukan kerjasama dan meningkatkan kinerja kemitraan dengan organisasi masyarakat, pelajar dan mahasiswa dan BNN masih bersifat kerja sendiri dalam pencegahan. BNN belum mampu menjangkau semua lapisan kelompok mahasiswa dan pelajar karena terbatasnya sumberdaya kurangnya inovasi gerakan yang efektif dan tersendatnya komunikasi.

Kegiatan edukasi Literasi Digital ini merupakan salah satu solusi untuk menjawab permasalahan yang dihadapi pemerintah khususnya BNN. Kegiatan ini merupakan sumbangsih dari akademisi melalui Program PKM yang merupakan salah satu dari Tri Dharma Perguruan Tinggi.

Kedepannya harus memaksimalkan peran digital sebagai alat kampanye dan pencegahan tanpa harus bertatap muka dan memberikan ruang publik kepada kader, relawan, penyuluh dan pegiat dalam bentuk konten dan tema kampanye yang edukatif, inovatif sesuai dengan kebutuhan dan kondisi generasi milenial saat ini.

\section{Ucapan Terima Kasih}


Ucapan terima kasih Tim PKM sampaikan kepada BNN Provinsi Kalimantan Barat yang telah menjadi partner dan memberikan support terhadap kegiatan ini. Ucapan terima kasih juga disampaikan kepada LPPM Universitas BSI Kampus Pontianak yang telah mendukung terlaksananya kegiatan PKM tersebut. Terakhir, Tim menyampaikan penghargaan dan ucapan terima kasih yang sebesar-besarnya kepada pihak Sekolah yang telah bersedia mengikuti kegiatan edukasi ini.

\section{Pendanaan}

Pendanaan kegiatan ini bersumber dari dana Mandiri, yang dikumpulkan dari seluruh anggota Tim PKM.

\section{Daftar Pustaka}

Akbar, F., Setiaji, S., Ishak, R., Saputra, D., \& Masruri, B. (2020). RANCANG BANGUN SISTEM INFORMASI KARANG TARUNA MENGGUNAKAN METODE WATERFALL. Jurnal Khatulistiwa Informatika, 8(1).

Azhar, A., Fikri, K. M. S., Siregar, V. A., \& Apriyanto, M. (2021). Pencegahan, Pemberantasan, Penyalahgunaan dan Peredaran Gelap Narkoba (P4GN) Pada PESANTREN. Jurnal Inovasi Penelitian, 1(11), 2463-2467.

Bakker, F. F., Putra, A. P., \& Putri, R. T. (2020). The Role of ASEAN in Tackling the Main Issues of Transnational Crime in the Southeast Asia Region. Journal of Law and Border Protection, 2(1), 47-58.

Gabriella, S. (2019). Kerjasama Indonesia-Interpol dalam menanggani isu penyeludupan narkoba di wilayah perbatasan Indonesia. Journal of International Studies, 3(2), 147-172.

Gafar, Y. (2011). PENANGGULANGAN PEREDARAN NARKOTIKA DI WILAYAH PERBATASAN KALIMANTAN BARAT (INDONESIA)-SARAWAK (MALAYSIA).

Humas BNN. (2021). Menanggulangi Narkoba Di Era Pandemi Covid-19 Menuju Indonesia Bersinar.

Kareth, N. V. J., \& Shintasari, R. (2020). Kebijakan Badan Narkotika Nasional Dalam Penanggulangan Narkoba Wilayah Perbatasan. Musamus Journal of Public Administration, 3(1), 20-31.

Lenny Tristia Tambun / BW. (2021). 27\% Pengguna Narkoba dari Kalangan Pelajar dan Mahasiswa.

Priangani, A., Kunkunrat, K., \& Nurindah, S. (2020). KERJASAMA INDONESIA- 
MALAYSIA DALAM MENANGANI PEREDARAN NARKOBA DI PERBATASAN. $\begin{array}{llll}\text { Jurnal Dinamika } & \text { Global, }\end{array}$ https://doi.org/https://doi.org/10.36859/jdg.v5i1.191

Saputra, D. (2021). SOSIALISASI ANTI HOAX, ANTI NARKOBA, SERTA PENGEMBANGAN UMKM DI DESA KUBU KABUPATEN KUBU RAYA. Mafaza: Jurnal Pengabdian Masyarakat, 1(1), 35-43.

Saputra, D., \& Rafiqin, A. (2017). Pembuatan Aplikasi Game Kuis "Pontianak Punye" Berbasis Android. Jurnal Khatulistiwa Informatika, 5(2). http://ejournal.bsi.ac.id/ejurnal/index.php/khatulistiwa/article/view/2882

Saufi, A., \& Kismartini, K. (2019). Peran Kemitraan Organisasi Masyarakat pada Pencegahan Narkoba di Kalangan Pelajar di Kota Pontianak. Konferensi Nasional Ilmu Administrasi, $3(1)$.

UNODC. (2021). UNODC World Drug Report 2021: pandemic effects ramp up drug risks, as youth underestimate cannabis dangers. 